\title{
Fluoride Contamination Studies in Belchampa- Pratappur Villages of Garhwa District Jharkhand
}

\author{
${ }^{1}$ Anshuman K.S., ${ }^{2}$ Subodh K.S. \\ ${ }^{1}$ Research Scholar, ${ }^{2}$ Associate Professor, Vinoba Bhave University, Department of Geology, \\ Hazaribag, Jharkhand, India. \\ 1anshumangeo0007@gmail.com, ${ }^{2}$ sinhask.geol@gmail.com
}

\begin{abstract}
Belchampa-Pratappur villages about $8 \mathrm{Kms}$ towards East from district head-quarter Garhwa has been undertaken to study the groundwater quality, especially fluoride contamination. These places are situated on the border of the Garhwa and Palamu district. Bishrampur is the prominent place lying to about $11 \mathrm{~km}$ east of area under consideration. The area is underlain mostly by granite and gneisses. Fluoride containing minerals as indeed Fluorite, apatite, different amphiboles and micas occur in association with these rocks. 18 Groundwater samples during Pre-and Post-monsoon have been collected from tube wells and analyzed for major cation $\left(\mathrm{Ca}^{+2}, \mathrm{Mg}^{+2}, \mathrm{Na}^{+}, \mathrm{K}^{+}\right)$and anion $\left(\mathrm{HCO}_{3}{ }^{-}, \mathrm{Cl}^{-}, \mathrm{SO}_{4}{ }^{2-}, \mathrm{F}^{-}\right)$in addition to fluoride. Fluoride concentration as high as $5 \mathrm{mg} / \mathrm{l} \mathrm{has} \mathrm{been} \mathrm{found} \mathrm{in} \mathrm{many} \mathrm{samples}$ of groundwater in the area, which is above the admissible limit of $1.5 \mathrm{mg} / \mathrm{l}$ (WHO). The inhabitants of these two villages belong to very poor economic background and of diverse communities. Many people of these villages are fluoride affected. Dental and Skeletal fluorosis is common in the area, which is very alarming. The total dissolved solid (T.D.S.) is also found to be much higher, at many places. It ranges from $586 \mathrm{mg} / \mathrm{l}$ to $408 \mathrm{mg} / \mathrm{l} \mathrm{in}$ pre-monsoon and $736 \mathrm{mg} / \mathrm{l}$ to $194 \mathrm{mg} / \mathrm{l}$ in post monsoon season respectively. Consequently the electrical conductivity is also much higher at several places which ranges from 915 micro mhos/cm to 637 micro mhos/cm at $25^{\circ} \mathrm{C}$ in pre-monsoon and $1150 \mathrm{micro} \mathrm{mhos} / \mathrm{cm}$ to 303 micro mhos/cm in post-monsoon season respectively.
\end{abstract}

In the present study the admeasurement pattern of fluoride concentration in the groundwater and its sources have been emphasized. Defluoridation has also been suggested to overcome the fluoride problems in the area.

Keywords:-Fluoride, Groundwater, Dental and Skeletal Fluorosis, Defluoridation

\section{INTRODUCTION}

Belchampa-Pratappur villages of Garhwa district comprising the study area are located at about $8 \mathrm{Kms}$ towards east from district head-quarters. Inflated value of fluoride in the ground water in the investigated region is highly vulnerable for drinking purposes. The quality and quantity of groundwater is very important in different fields such as irrigation, Industrial and community water supply. From 25 nations around 200 million people have considerable health issues, with inflated fluoride level in potable water. About 60-65 million people in India consume fluoride defilement in groundwater and the number contrived by fluorosis is reckoning about 2.5 to 3 million in numerous states, particularly Andhra Pradesh, Bihar, Jharkhand, Gujarat, Madhya Pradesh, Punjab, Rajasthan, Tamilnadu and Uttar Pradesh. Fluoride containing minerals like Fluorspar $\left(\mathrm{CaF}_{2}\right)$, Fluorapatite $\left[\mathrm{Ca}_{5}\left(\mathrm{Po}_{4}\right)_{3} \mathrm{~F}\right]$, Cryolite and hydroxylapatite in rocks are the paramount fountainhead of fluoride in groundwater. Small amount of fluoride is essential for normal mineralization of bones and shaping of dental enamel .Excessive consumption of fluoride by way of water and food consumption can cause dental and skeletal fluorosis. Due to its strong electronegativity, fluoride is attracted towards positively charged calcium present in teeth and bones. In the agrarian as well as urban areas groundwater forms a crucial integrant of water supply. Fresh water reservoirs comprise the most significant resources to succour quality life and hence, fit to supply of water in terms of quality and quantity is indespensible. 


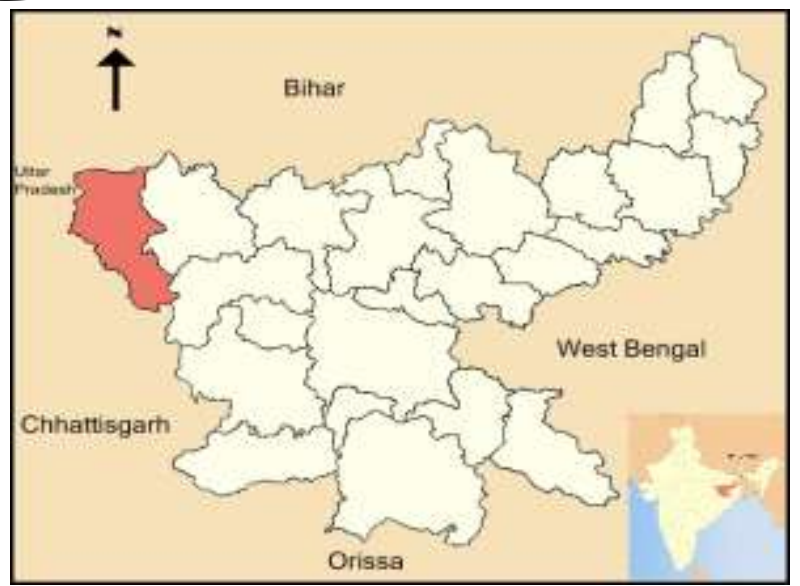

District map of Garhwa

\section{MATERIALS AND METHODS}

The study area Belchampa-Pratappur are small villages in Garhwa district of Jharkhand. The area under study is agrarian, there is no other source of water rather than groundwater. Societal and economical status of the villagers is very indigent. The dwellers mainly depend on tillage and allied occupation, suffering from disparate level of undernutrition. Interaction with the villagers were made and several fluoride affected persons were examined.
The survey involved water sample collection from public and private hand pumps. 18 water samples were collected and were first tested on-site using the field test kit. Field test require collection of $50 \mathrm{ml}$ of water samples in the test tube and then $2.5 \mathrm{ml}$ of Zirconyl Alizarine was added to it. The water sample was consent to stand for 25-30 minutes for arrant reaction and colour development. The presence of yellow colour in water sample shows the existance of inflated concentration of fluoride beyond admissible limit. The sampling locations were recorded by Global Positioning System (GPS). Field test was followed by laboratory test using ION METER METHOD. In the analysis, samples with more than $1.5 \mathrm{mg} / \mathrm{l}$ of fluoride concentration are alluded to as non permissible (NP) and with fluoride concentration lower than $1.5 \mathrm{mg} / \mathrm{l}$ is permissible $(\mathrm{P})$. The major cations $\mathrm{Ca}, \mathrm{Mg}, \mathrm{Na}, \mathrm{K}$ and anions $\mathrm{F}, \mathrm{Hco}_{3}, \mathrm{Cl}, \mathrm{SO}_{4}$ were analyzed in addition to $\mathrm{EC}$ and $\mathrm{pH}$ values were calculated in the field using portable conductivity and $\mathrm{pH}$ meter respectively. Major anions (F, $\mathrm{HcO}_{3}, \mathrm{Cl}, \mathrm{So}_{4}$ ) and cations ( $\mathrm{Ca}, \mathrm{Mg}, \mathrm{Na}, \mathrm{K}$ ) were measured by Ion-Chromatograph. All the concentrations are expressed in $\mathrm{mg} / \mathrm{l}$ except $\mathrm{pH}$ and $\mathrm{EC}$. EC is expressed in $\mathrm{mho} / \mathrm{cm}$ at $25^{\circ} \mathrm{C}$. The chemical data of groundwater samples are shown in table- 1 and table 2.

Table 1 (pre-monsoon)

\begin{tabular}{|l|l|l|l|l|l|l|l|l|l|l|l|l|l|l|}
\hline Place & $\begin{array}{l}\text { Sample } \\
\text { ID }\end{array}$ & $\mathrm{pH}$ & $\mathrm{EC}$ & $\mathrm{TH}$ & $\mathrm{TDS}$ & $\mathrm{Ca}^{2+}$ & $\mathrm{Mg}^{2+}$ & $\mathrm{Na}^{+}$ & $\mathrm{K}^{+}$ & $\mathrm{HCO}_{3}^{-}$ & $\mathrm{Cl}^{-}$ & $\mathrm{F}^{-}$ & $\mathrm{SO}_{4}^{-}$ & $\mathrm{SAR}^{-1}$ \\
\hline Gathiahitola & KW-1 & 7.21 & 915 & 338 & 586 & 107.2 & 17 & 53.6 & 4.9 & 260 & 64 & 2 & 38.5 & 0.947 \\
\hline Gathiahitola & KW-2 & 7.42 & 637 & 136 & 408 & 48 & 3.9 & 47.7 & 4.4 & 292 & 8 & 4 & 7.5 & 1.297 \\
\hline Patsatola & KW-3 & 7.32 & 816 & 189 & 522 & 91.7 & 14.2 & 46.4 & 3.8 & 199 & 17 & 2.5 & 18.2 & 0.888 \\
\hline Darmitola & KW-4 & 7.17 & 885 & 236 & 566 & 102.3 & 11.5 & 39.9 & 2.8 & 287 & 52 & 1.7 & 29.2 & 0.734 \\
\hline Bhaishmarwa Tola & KW-5 & 7.36 & 865 & 282 & 554 & 52.3 & 4.4 & 27.1 & 2.8 & 213 & 21 & 0.8 & 11.1 & 0.705 \\
\hline Side Khurd & KW-6 & 7.21 & 789 & 263 & 518 & 75 & 14.2 & 62.3 & 6.8 & 280 & 57 & 4.8 & 46.8 & 0.804 \\
\hline Monaha Tola & KW-7 & 7.43 & 756 & 204 & 502 & 64 & 10.7 & 56.4 & 5.3 & 216 & 50 & 5 & 28.6 & 1.303 \\
\hline Monaha Tola & KW-8 & 7.04 & 868 & 254 & 552 & 89.6 & 7.3 & 58.3 & 5.5 & 224 & 54 & 4.5 & 52.2 & 1.287 \\
\hline Bhaishmarwa Tola & KW-9 & 6.92 & 766 & 232 & 486 & 83.2 & 5.8 & 51.5 & 4.9 & 268 & 34 & 4 & 39.4 & 1.161 \\
\hline
\end{tabular}

Table -2 (Post-monsoon)

\begin{tabular}{|l|l|l|l|l|l|l|l|l|l|l|l|l|l|l|}
\hline Place & $\begin{array}{l}\text { Sample } \\
\text { ID }\end{array}$ & $\mathrm{pH}$ & $\mathrm{EC}$ & $\mathrm{TH}$ & $\mathrm{TDS}$ & $\mathrm{Ca}^{2+}$ & $\mathrm{Mg}^{2+}$ & $\mathrm{Na}^{+}$ & $\mathrm{K}^{+}$ & $\mathrm{HCO}_{3}^{-}$ & $\mathrm{Cl}^{-}$ & $\mathrm{F}^{-}$ & $\mathrm{SO}_{4}^{-}$ & $\mathrm{SAR}^{-1}$ \\
\hline Gathiahi tola & KW-1 & 7.81 & 1150 & 456 & 736 & 164 & 11.2 & 58.6 & 3.8 & 208 & 61 & 1 & 38.5 & 0.867 \\
\hline Gathiahi tola & KW-2 & 7.15 & 697 & 288 & 446 & 65.6 & 30.1 & 64.2 & 4.2 & 300 & 52 & 3 & 29.8 & 1.332 \\
\hline Patsa tola & KW-3 & 7.12 & 813 & 256 & 520 & 73.6 & 17.5 & 76.8 & 5.3 & 336 & 15 & 2 & 16.5 & 1.593 \\
\hline Darmi tola & KW-4 & 7.65 & 522 & 220 & 334 & 29.6 & 35.4 & 38.9 & 2.7 & 276 & 39 & 0.9 & 21.2 & 0.988 \\
\hline $\begin{array}{l}\text { Bhaishmarwa } \\
\text { Tola }\end{array}$ & KW-5 & 7.33 & 631 & 282 & 404 & 72 & 24.7 & 61.9 & 4.3 & 304 & 43 & 1 & 24.3 & 1.254 \\
\hline Side Khurd & KW-6 & 7.59 & 303 & 100 & 194 & 32 & 4.8 & 32.5 & 6.2 & 104 & 29 & 3 & 48.9 & 1.055 \\
\hline Monaha Tola & KW-7 & 7.05 & 731 & 180 & 468 & 36 & 21.8 & 68.4 & 5.9 & 244 & 66 & 5 & 38.2 & 1.813 \\
\hline Monaha Tola & KW-8 & 7.84 & 522 & 160 & 334 & 36 & 17 & 78.1 & 4.3 & 44 & 36 & 5 & 51.1 & 2.151 \\
\hline $\begin{array}{l}\text { Bhaishmarwa } \\
\text { Tola }\end{array}$ & KW-9 & 7.29 & 319 & 126 & 204 & 41.6 & 5.3 & 39.4 & 28.3 & 120 & 13 & 3 & 44.7 & 1.131 \\
\hline
\end{tabular}




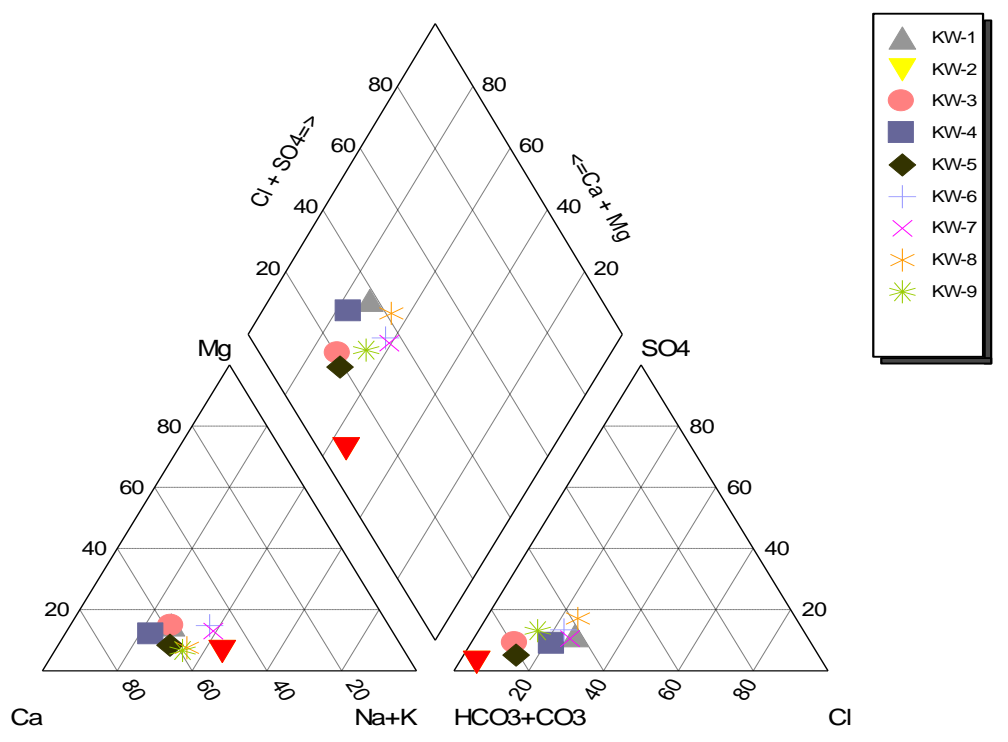

Fig 1 (a) :- Piper trilinear diagram showing chemical characters of ground water, (pre Monsoon)

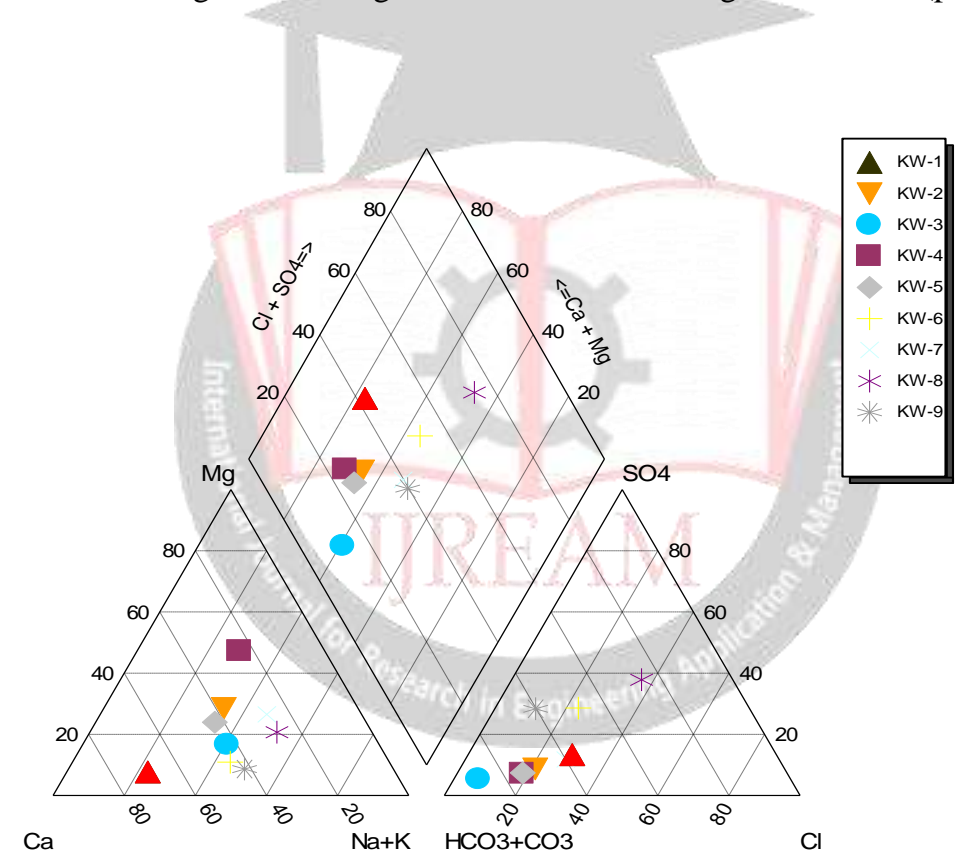

Fig 1 (b) :- Piper trilinear diagram showing chemical characters of ground water,(Post Monsoon)

The quality of groundwater based on piper trilinear diagram.

\begin{tabular}{ll}
\hline Various segments of the diamond shaped field & $\begin{array}{l}\text { Characteristics of corresponding each small parts of } \\
\text { diamond field }\end{array}$ \\
1. & Alkaline earth $(\mathrm{Ca}+\mathrm{Mg})$ exceeds alkalies $(\mathrm{Na}+\mathrm{K})$ \\
2. & Alkalies exceeds alkaline earths \\
3. & Weak acids $\left(\mathrm{CO}_{3}+\mathrm{HCO}_{3}\right)$ exceeds strong acids $\left(\mathrm{SO}_{4}+\mathrm{Cl}+\mathrm{F}\right)$ \\
4. & Strong acids exceeds weak acids \\
5. & Carbonate hardness (secondary salinity) exceeds $50 \%$ \\
6. & Non-Carbonate hardness (secondary salinity) exceeds $50 \%$ \\
7 & Non-Carbonate alkali (primary salinity exceeds $50 \%)$ \\
8. & Carbonate alkali (Primary alkalinity) exceeds $50 \%$ \\
9. & Non of the cation or anion pairs exceeds $50 \%$ \\
\hline
\end{tabular}


Plot of the groundwater samples in piper's Trilinear diagram of Pre monsoon data falls in the field 1 and 3 suggesting alkaline earth $(\mathrm{Ca}+\mathrm{Mg})$ exceeds alkalies $(\mathrm{Na}+\mathrm{K})$ and weak acids $\left(\mathrm{CO}_{3}+\mathrm{HCO}_{3}\right)$ exceeds strong acids $\left(\mathrm{SO}_{4}+\mathrm{Cl}+\mathrm{F}\right)$ respectively. $\mathrm{Samples}$ of post monsoon data falls in field 1 and 3. Plot in field 3 (more than 80\%) indicates that weak acids exceeds strong acids (fig 1a \& 1b)

\section{Sodium AbSORPTION RATIO (SAR)}

The concentration of sodium in groundwater is important as increase of sodium concentration in water affects the soil properties reducing permeability, Kelly (1951) and Tijani (1994). The process leading to the cation exchange reactions in soil may be studied from sodium absorption ratio (SAR) (U.S.Salinity laboratory, 1994)

SAR is expressed as :-

$\mathrm{SAR}=\mathrm{Na}^{+} / \sqrt{\mathrm{Ca}^{++}}+\mathrm{Mg}^{++} / 2$

Where the concentration are expressed in equivalent per million (epm)

Classification of water with reference to SAR (Herman Bouwer, 1978) is presented in table 3 . All the 18 samples of pre and post monsoon seasons fall under no problem category.

Table-3 Classification of sodium absorption ratio in groundwater

\begin{tabular}{|c|c|c|c|}
\hline SAR & Water quality & $\begin{array}{c}\text { Pre- monsoon } \\
\text { (no.of samples) }\end{array}$ & $\begin{array}{c}\text { Post-monsoon } \\
\text { (no.of samples) }\end{array}$ \\
\hline $0-6$ & No problem & 09 & 09 \\
\hline $6-9$ & Increasing problem & 0 & 0 \\
\hline$>9$ & Severe problems & 0 & 0 \\
\hline
\end{tabular}

\section{Irrigation Water Quality:}

The polluted water creates toxicity, water infiltration and salinity (Ayers and westcot, 1985). The parameters like EC, TDS, SAR, MAR, SSP, RSBC, PI, KR, sodium percentage etc. (Michel 1992; Raghunath 1987) are determined and compared with national and international standards to assess the water quality for irrigation purposes of the study area. The Statistical summary of the chemical composition of groundwater are given in Table-4, and irrigation quality parameters of groundwater samples of the study area is shown inTable-5.

Table-4: Statistical summary of the chemical composition of groundwater

\begin{tabular}{|c|c|c|c|c|c|c|c|c|c|}
\hline \multirow[t]{2}{*}{ Parameter } & \multirow[t]{2}{*}{ Unit } & \multicolumn{2}{|c|}{ Minimum } & \multicolumn{2}{|c|}{ Maximum } & \multicolumn{2}{|c|}{ Arithmetic Mean } & \multicolumn{2}{|c|}{ Standard deviation } \\
\hline & & $\begin{array}{c}\text { Pre } \\
\text { monsoon }\end{array}$ & $\begin{array}{c}\text { Post } \\
\text { monsoon }\end{array}$ & $\begin{array}{c}\text { Pre } \\
\text { monsoon }\end{array}$ & $\begin{array}{c}\text { Post } \\
\text { monsoon }\end{array}$ & $\begin{array}{c}\text { Pre } \\
\text { monsoon }\end{array}$ & $\begin{array}{c}\text { Post } \\
\text { monsoon }\end{array}$ & $\begin{array}{c}\text { Pre } \\
\text { monsoon }\end{array}$ & $\begin{array}{c}\text { Post } \\
\text { monsoon }\end{array}$ \\
\hline Temperature & ${ }^{\circ} \mathrm{C}$ & 19 & 11 & 24 & 15 & 21.78 & 12.9 & 1.64 & 1.27 \\
\hline $\mathrm{pH}$ (lab) & pH unit & 7.21 & 7.05 & 7.42 & 7.84 & 7.32 & 7.43 & 0.0525 & 0.303 \\
\hline El. Cond. & $\mathrm{uS} / \mathrm{cm}$ & 637 & 303 & 915 & 1150 & 810.8 & 632 & 85.4 & 261.1 \\
\hline TDS & $\mathrm{mg} / \mathrm{l}$ & 408 & 194 & 586 & 736 & 521.6 & 404.4 & 53.2 & 167.1 \\
\hline $\mathrm{Ca}$ & $\mathrm{mg} / \mathrm{l}$ & 48 & 29.6 & 107.2 & 164 & 79.3 & 61.2 & 21.05 & 42.4 \\
\hline $\mathrm{Mg}$ & $\mathrm{mg} / \mathrm{l}$ & 3.9 & 4.8 & 17 & 35.4 & 9.89 & 18.64 & 4.75 & 10.53 \\
\hline $\mathrm{Na}$ & $\mathrm{mg} / \mathrm{l}$ & 27.1 & 32.5 & 62.3 & 78.1 & 49.2 & 57.6 & 10.7 & 16.88 \\
\hline K & $\mathrm{mg} / \mathrm{l}$ & 2.8 & 2.7 & 6.8 & 28.3 & 4.58 & 7.22 & 1.298 & 7.98 \\
\hline $\mathrm{Cl}$ & $\mathrm{mg} / 1$ & 8 & 13 & 64 & 66 & 39.7 & 39.3 & 20.17 & 18.57 \\
\hline $\mathrm{HCO} 3$ & $\mathrm{mg} / \mathrm{l}$ & 199 & 44 & 292 & 336 & 248.8 & 215.1 & 35.8 & 103.1 \\
\hline SO4 & $\mathrm{mg} / \mathrm{l}$ & 7.5 & 16.5 & 52.2 & 51.1 & 30.17 & 34.8 & 15.58 & 12.46 \\
\hline$F$ & $\mathrm{mg} / \mathrm{l}$ & 0.8 & 0.9 & 5 & 5 & 3.256 & 2.656 & 1.528 & 1.595 \\
\hline
\end{tabular}

Table 5: Irrigational quality parameters of groundwater samples of the study area

\begin{tabular}{|c|c|c|c|c|c|c|c|c|c|c|}
\hline \multirow[t]{2}{*}{ Station ID } & \multirow[t]{2}{*}{ Place } & \multirow[t]{2}{*}{ Season } & \multicolumn{8}{|c|}{ PARAMETERS } \\
\hline & & & EC & TDS & SAR & MAR & SSP & RSBC & PI & KR \\
\hline \multirow[t]{2}{*}{ KW-1 } & \multirow[t]{2}{*}{ Gathiahi Tola } & Pre monsoon & 915 & 586 & 1.27 & 20.73 & 26.69 & -1.08 & 48.42 & 0.34 \\
\hline & & Post monsoon & 1150 & 736 & 1.19 & 10.12 & 22.51 & -4.77 & 37.71 & 0.27 \\
\hline \multirow[t]{2}{*}{ KW-2 } & \multirow[t]{2}{*}{ Gathiahi Tola } & Pre monsoon & 637 & 408 & 1.78 & 11.82 & 44.61 & 2.39 & 88.98 & 0.76 \\
\hline & & Post monsoon & 697 & 446 & 1.64 & 43.07 & 33.52 & 1.64 & 58.65 & 0.48 \\
\hline \multirow[t]{2}{*}{ KW-3 } & \multirow[t]{2}{*}{ Patsa Tola } & Pre monsoon & 816 & 522 & 1.19 & 20.34 & 26.91 & -1.31 & 49.27 & 0.35 \\
\hline & & Post monsoon & 813 & 520 & 2.08 & 28.16 & 40.47 & 1.83 & 67.28 & 0.65 \\
\hline
\end{tabular}




\begin{tabular}{|c|c|c|c|c|c|c|c|c|c|c|}
\hline \multirow[t]{2}{*}{ KW-4 } & \multirow[t]{2}{*}{ Darmi Tola } & Pre monsoon & 885 & 566 & 0.99 & 15.64 & 23.0 & -0.39 & 50.15 & 0.28 \\
\hline & & Post monsoon & 522 & 334 & 1.14 & 66.35 & 28.63 & 3.04 & 62.79 & 0.38 \\
\hline \multirow[t]{2}{*}{ KW-5 } & \multirow{2}{*}{$\begin{array}{c}\text { Bhaishmarwa } \\
\text { Tola }\end{array}$} & Pre monsoon & 865 & 554 & 0.98 & 12.18 & 29.61 & 0.88 & 73.43 & 0.39 \\
\hline & & Post monsoon & 631 & 404 & 1.60 & 36.13 & 33.25 & 1.39 & 59.21 & 0.47 \\
\hline \multirow[t]{2}{*}{ KW-6 } & \multirow[t]{2}{*}{ Side khurd } & Pre monsoon & 789 & 518 & 0.73 & 23.80 & 37.0 & 0.84 & 63.67 & 0.55 \\
\hline & & Post monsoon & 303 & 194 & 1.41 & 19.83 & 44.11 & 0.10 & 79.86 & 0.70 \\
\hline \multirow[t]{2}{*}{ KW-7 } & \multirow[t]{2}{*}{ MonahaTola } & Pre monsoon & 756 & 502 & 0.72 & 21.61 & 38.85 & 0.34 & 66.41 & 0.60 \\
\hline & & Post monsoon & 731 & 468 & 2.22 & 49.96 & 46.54 & 2.20 & 75.78 & 0.82 \\
\hline \multirow[t]{2}{*}{ KW-8 } & \multirow[t]{2}{*}{ MonahaTola } & Pre monsoon & 868 & 552 & 0.59 & 11.84 & 34.54 & -0.79 & 58.52 & 0.50 \\
\hline & & Post monsoon & 522 & 334 & 2.68 & 43.78 & 52.32 & -1.07 & 64.41 & 1.06 \\
\hline \multirow[t]{2}{*}{ KW-9 } & \multirow{2}{*}{$\begin{array}{c}\text { Bhaishmarwa } \\
\text { Tola }\end{array}$} & Pre monsoon & 766 & 486 & 1.47 & 10.31 & 33.82 & 0.24 & 63.13 & 0.48 \\
\hline & & Post monsoon & 319 & 204 & 1.52 & 17.36 & 49.25 & -0.10 & 73.75 & 0.68 \\
\hline
\end{tabular}

SAR-Sodium Absorption Ratio, SSP-Soluble Sodium Percentage, PI-Permeability Index, KR-Kelly's Ratio, RSBC-Residual Sodium Bicarbonate, MAR-Magnesium Absorption Ratio.

TDS is the important parameter for the water quality for irrigation purpose which is usually affected by topography, lithology of aquifer, recharge, runoff and discharge conditions of groundwater because the toxic materials may settled in the water which is harmful for plants (Matthess 1982). TDS in the study area varies from 408 to $586 \mathrm{mg} / \mathrm{l}$ for pre monsoon and 194 to $736 \mathrm{mg} / \mathrm{l}$ for post monsoon (table-4 and 5). All the samples for pre monsoon and post monsoon were within maximum permissible limit for study area by BIS (BIS Standards 1998). TDS of water samples in the study area have values less than 1000mg/l indicating that water is non-saline which is good for irrigation. The EC in the study area varies from 637 to $915 \mu \mathrm{S} / \mathrm{cm}$ for pre monsoon and 303 to $1150 \mu \mathrm{S} / \mathrm{cm}$ for post monsoon (table-4 and 5) which is within permissible limit $(<1500 \mu \mathrm{S} / \mathrm{cm}$ ) (BIS Standards 1998).

Table 6: Irrigation water quality parameters by BIS 1998

\begin{tabular}{|c|c|c|c|}
\hline S.No. & Parameters & Unit & BIS-Limit (1998) \\
\hline 1 & Electrical Conductivity (EC) & $\mu \mathrm{S} / \mathrm{cm}$ & 1500 \\
\hline 2 & TDS & $\mathrm{Mg} / \mathrm{L}$ & 2000 \\
\hline
\end{tabular}

The Sodium Absorption Ratio (SAR) is effective parameter for water used in agriculture (Ayers and Westcot 1985) There is significant relationship to which $\mathrm{Na}^{+}$is absorbed by the soil (Raihan and Alam 2008). The permeability of soil is reduced when $\mathrm{Na}^{+}$is present in irrigation water and its continuous use makes the soil impermeable. However the presence of $\mathrm{Ca}^{2+} \mathrm{or} \mathrm{Mg}^{2+}$ salts reduces the harmful effect of $\mathrm{Na}^{+}$and increases the permeability of soil (Punmia and Lal 1981; Asaduzzaman 1985). The SAR values of irrigation in the study area varies from 0.59 to 1.78 in pre monsoon and 1.14 to 2.68 in post monsoon are within standard limit and excellent for irrigation. According to U.S. Salinity all water samples of pre monsoon shows low sodium hazard and high salinity hazard except one sample KW-2 which shows medium salinity hazard. Water samples of post monsoon show low sodium hazard and medium salinity hazard except two samples KW-1 and KW-3 which show high salinity hazard. Again soluble sodium percentage (SSP) values (table-5) indicates the suitability of irrigation water of the study area of pre monsoon and post monsoon varies from good to fair.

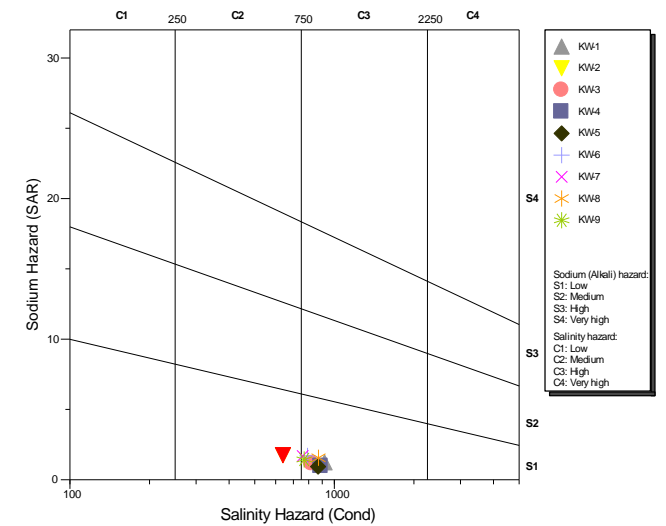

(a)

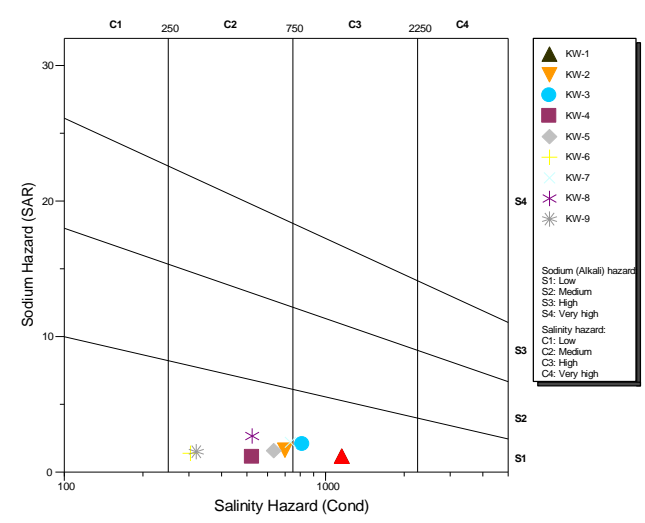

(b)

Fig 2 a : U.S. Salinity diagram for groundwater of the study area (a) pre monsoon (b) post monsoon 
The RSBC value of water of both the pre monsoon and post monsoon of the study area are $<5$ meq/l belongs to satisfactory level for irrigation purpose (Gupta and Gupta 1987). The -ve value of RSBC indicates excess concentration of $\mathrm{HCO}_{3}{ }^{-}$in $\mathrm{water}^{-}$ of the study area (table-5). Again, the Permeability Index (PI) of the study area shows satisfactory level for irrigation. The PI values ranges from 48.42 to $88.98 \%$ in pre monsoon and 37.71 to $79.86 \%$ in post monsoon (table-5). Nearly $11 \%$ of the samples fall under Class-I category and another $89 \%$ of samples belong to Class-II category in pre monsoon while nearly 22 $\%$ of samples fall under Class-I category and another $78 \%$ of samples belong to Class-II category in post monsoon indicating the quality of water is good and moderate respectively for irrigation purposes.

In water samples the balance among $\mathrm{Na}^{+}, \mathrm{Ca}^{2+}$ and $\mathrm{Mg}^{2+}$ can be indicated by Kelley's ratio (KR). For irrigation purpose the KR value should not exceed 1 (Kelley 1963). The value of KR more than 1 shows excess of $\mathrm{Na}^{+}$in water. The KR value of all the water samples of the study area in pre monsoon and post monsoon are <1 (except KW-8 in post monsoon) which satisfy that most of the samples fall under suitable for irrigation.

High concentration of $\mathrm{Mg}^{2+}$ in water affects the quality of soil (Kumar 2007). Therefore, the value Magnesium Adsorption Ratio (MAR) should not exceeds 50 (Gupta and Gupta 1987). The MAR values in the study area in pre monsoon and post monsoon fall under permissible limit, i.e., less than 50 (except KW-4 in post monsoon) indicates that there is no such effect to the soil.

Table 7: Limits of some important parameters for irrigation water quality (According to Ayers and Westcot (1985), Gupta and Gupta (1987), Todd (1980) and Wilcox (1955)

\begin{tabular}{|c|c|c|c|}
\hline S.No. & Parameters & Range & Suitable for irrigation \\
\hline 1 & SAR & $<10$ & Excellent \\
Good \\
Doubtful \\
Unsuitable
\end{tabular}

SAR-Sodium Absorption Ratio, SSP-Soluble Sodium Percentage, PI-Permeability Index, KR-Kelly's Ratio, RSBC-Residual Sodium Bicarbonate, MAR-Magnesium Absorption Ratio.

Drinking water standards recommended by WHO (1984), BIS (1991) and IS-10500 are shown in table -8

\begin{tabular}{|c|c|c|c|c|}
\hline Parameters & WHO(1984) & BIS(1991) & $\begin{array}{c}\text { IS:10500 Requirement } \\
\text { (Desirable limit) }\end{array}$ & Effects when beyond the desirable limits. \\
\hline $\mathrm{pH}$ & $6.5-8.5$ & $7.0-8.5$ & $6.5-8.5$ & $\begin{array}{l}\text { The mucous membrane and/or water supply } \\
\text { system. }\end{array}$ \\
\hline TDS & 1000.0 & 500 & - & $\begin{array}{c}\text { Delectability decreases and may cause } \\
\text { gastrointestinal irritation. }\end{array}$ \\
\hline $\mathrm{Ca}_{2}$ & 500 & 75 & 75 & Inlay in water supply structure. \\
\hline $\mathrm{Mg}_{2}$ & - & 30 & 30 & Inlay in water supply structure. \\
\hline $\mathrm{Na}$ & 200 & - & - & Hypertension or heart diseases. \\
\hline $\mathrm{Cl}$ & 250 & 250 & 250 & Taste, Corrosion and Palatability are affected. \\
\hline $\mathrm{So}_{4}$ & 400 & 150 & 150 & - \\
\hline $\mathrm{No}_{3}$ & 45 & 45 & 45 & - \\
\hline $\mathrm{F}$ & 1.5 & $0.6-1.5$ & $0.6-1.2$ & Cause skeletal fluorosis. \\
\hline
\end{tabular}




\section{RESULTS AND DISCUSSION}

Fluoride concentration in the investigated region ranges from $0.3 \mathrm{mg} / \mathrm{l}$ to $5 \mathrm{mg} / \mathrm{l}$. The inflated concentration of fluoride may be because of rock water interaction. The granitic rocks of the area contain fluoride containing minerals such as Fluorite, Cryolite, Fluorspar, Apatite, and Hydroxylapatite . Also, over its complicated pour history, groundwater passes through different geological configuration leading to consequent contamination in shallow aquifers which is primarily tapped for potable water supply in the area. Therefore, groundwater contains more fluoride than surface water resources due to greater contact times with fluoride-containing minerals in rockwater interactions.

Further, looking into fluoride concentration, it was found that Darmi tola, Gathiahi tola and Bhaishmarwa tola which is under Garhwa district, is not affected by higher concentration of fluoride, whereas, Monaha tola, Side khurd and Bhaismarwa tola are highly affected by Fluoride (5mg/l).

With reference to permissible limit $(0.5-1.5 \mathrm{mg} / \mathrm{l})$ it can be stated that Monaha tola followed by Bhaismarwa tola and Side khurd have high percentage of fluoride under non admissible limit. However, maximum Fluoride concentration $(5.0 \mathrm{mg} / \mathrm{l})$ was found in Monaha tola, Side khurd and bhaismarwa tola in Pre and Post monsoon seasons respectively. Fluoride concentrations exceeding $2.5 \mathrm{mg} / \mathrm{l}$ in the potable water appears to be censorions to cause acute forms of Skeletal fluorosis. Samples with non permissible concentration of Fluoride, on and average, indicate higher proportion in Monaha tola, Side khurd and Bhaishmarwa tola as compared to that of Darmi tola, Gathiahi tola and Bhaishmarwa tola. Further looking into fluoride concentration beneath the permissible limit of $0.5 \mathrm{mg} / \mathrm{l}$, it was found that there is only one area that is Bhaishmarwa tola having fluoride concentration below lower permissible limit in pre-monsoon season and three areas i.e. Darmi tola, Gathiahi tola and Bhaishmarwa tola in post-monsoon season respectively.

Local people of the area are suffering from dental and skeletal fluorosis.

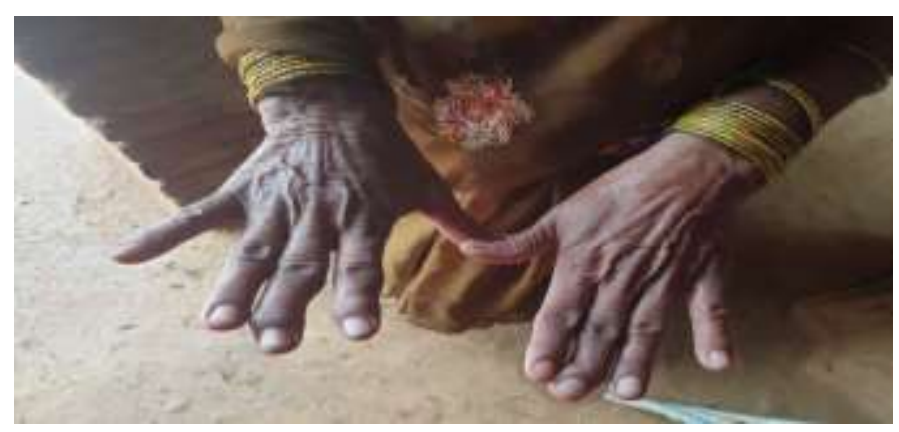

Fig 3 a:- A woman suffering from skeletal fluorosis, the fingers appear affected.

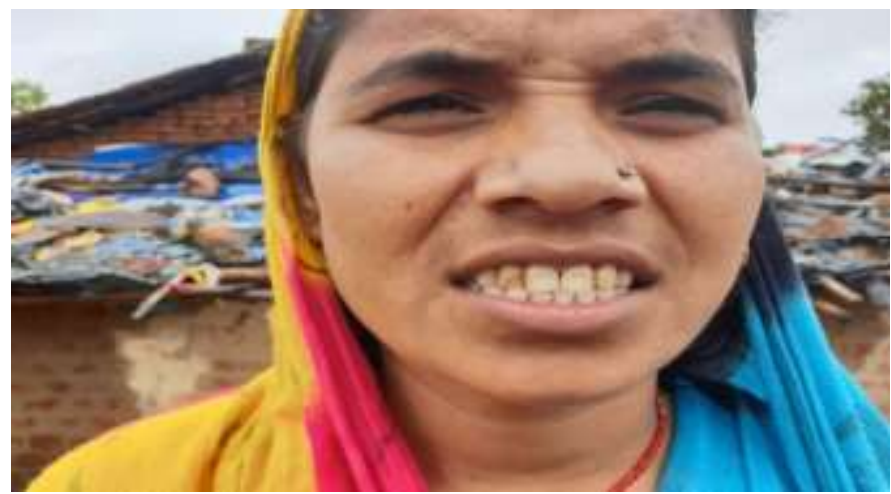

Fig 3 b:- A women suffering from dental fluorosis

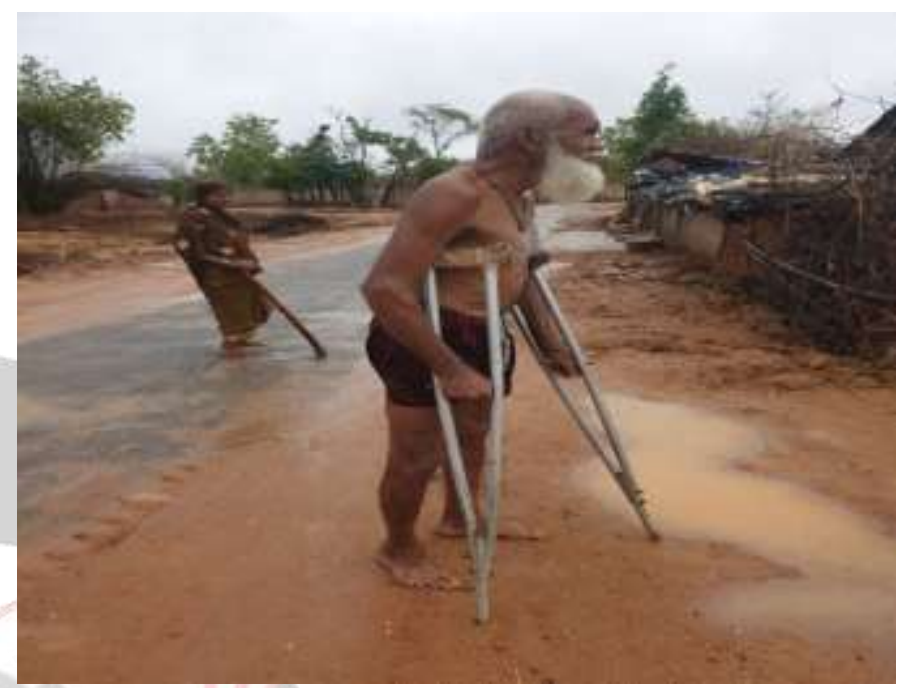

Fig 3 c :- A man suffering from skeletal fluorosis, back bone and legs appear affected.

\section{Defluoridation Technique}

Fluoride is usually reported as a 'double-edged sword' as pathetic consumption is associated with dental caries, where as redundant intake causes dental, skeletal and soft tissue fluorosis- which is uncurable. There are various techniques and materials were applied all over the world for Bone char, Brick pieces column, Mud pot, Natural adsorbents, Defluoridation by Ion-exchange technique, Defluoridation by Ion-Exchange technique, Defluoridation by precipitation technique, Nalgonda technique etc.

Mud pot technique and Nalgonda technique can be emphasized for study area, in which Nalgonda technique is more promising. After immeasurable examination of many rmaterials and processes involving activated alumina since 1961, National Environmental Engineering Research Institute (NEERI) Nagpur has included an efficient and simple method for normal elimination of fluoride which is named as 'Nalgonda Technique'

Nalgonda Technique involves addition of Aluminium salts, lime and bleaching powder followed by rapid mixing, flocculation, sedimentation, filtration and disinfection. Aluminium salt may be added as aluminium sulphate (alum) or aluminium chloride or amalgamation of these two. They are responsible for removal of fluoride from water. 
There are many advantages of Nalgonda technique like.

No handling of caustic acids and alkalies. The chemicals requisite are easily available and are used in commonly in municipal water Treatment. Economical and Can be used to treatment of water in large quantities for communal usage. Simplicity of design, construction, operation and maintenance. Local semi-skilled workers can be easily employed. Highly potent in removal of fluorides from high levels to desirable levels. It provides de-fluoridated water of uniform acceptable quality.

\section{CONClusion}

The Fluoride concentration was detected at inflated levels in potable water of Belchampa-Pratappur village of Garhwa district. Very high fluoride concentrations (up to $5.0 \mathrm{mg} \mathrm{L}$ ${ }^{1}$ ) are found in the public hand pumps in Monaha tola and Bhaismarwa tola. At places the lower percentage of non permissible at superficial depth may be attributed to possible recharge of groundwater from surface sources, At deeper level, more than 250 feet, less groundwater discharge along with possibility of fluoride absorption, its higher concentration cannot be ruled out. This indicates that shallow aquifers are safer than deep aquifers. The artificial recharge to groundwater may reduce fluoride concentration.

Among the water sources examined, water samples collected from Monahatola and Bhaismarwatola have about $100 \%$ of samples respectively with fluoride concentration in non-permissible limits. Therefore, the remedial measures to reduce Fluoride concentration needs to be taken.

It would be important to determine the health problems that might be caused by higher Fluoride intake in this region to determine the gravity of the problems. The Monahatola, Bhaismarwatola and Pratappur-Belchampa areas need to be looked for high concentration of Fluoride and related diseases whereas, Patsa tola and Darmi tola for lower concentration of fluoride and related diseases.

\section{ACKNOWLEDGMENT}

Authors are thankful to Sri Umesh Das, Yugantar Bharati, Ranchi for providing the water quality data on fluoride concentration for the study area. Authors also express their gratitude to authorities of Vinoba Bhave University for providing required chemicals for analytical work.

\section{REFERENCES}

[1] Adnan, S.,N. Shahid and j. Talha,2005. Groundwater quality assessment in and around kalu khuhar, super highway,sindh,Pakistan.j.Applied sci.,5: 1260-1265.

[2] Asaduzzaman M (1985) Handbook of groundwater and wells. BRACProkashana, Dhaka

[3] Ayers RS, Westcot DW (1985) Water quality for agriculture, irrigation and drainage (Paper No. 29). FAO, Rome
[4] Ayoob, S. and A.K.Gupta, 2006. Fluoride in drinking water: (A review on the status and stress effects. crit. Re Morocco).J.Afr.Earth Sci; 39: 509-516.433-487

[5] Bureau of Indian Standards (BIS), (1991), Indian Standard Specification for drinking water. IS 10500, PP 2-4

[6] Das, Subhajyoti (2011) Groundwater Resources of India, National Book Trust, India.

[7] Gupta SK, Gupta IC (1987) Management of saline soils and waters,Oxford and IBH Publishing Company, New Delhi

[8] IMCR (1975) Indian Council of Medical Research; Manual of standards of Quality of drinking water supplies.

[9] ISI (Indian Standard Institute) (1983) Indian standard specification for drinking water, IS 10500.

[10] Kelley WP (1963) Use of saline irrigation water. Soil Sci 95:355-391

[11] Kumari, Neeta., Pathak, Gopal., Singh, Thakur Brahmanand.,(2015). The overall assessment of quality and quantity of drinking water focus on fluoride.

[12] Kumar M, Kumari K, Ramanathan AL, Saxena R (2007) Acomparative evaluation of groundwater suitability for irrigationand drinking purposes in two intensively cultivated districts ofPunjab, India. Environ Geol 53:553-574

[13] Matthess G (1982) The properties of ground water. Wiley, New York

[14] Michael AM (1992) Irrigation theory and practices. Vikash Publishing House Pvt. Ltd., New Delhi

[15] Punmia BC, Lal PBB (1981) Irrigation and water power engineering Standard Publishers Distributors, New Delhi

[16] Raghunath HM (1987) Groundwater. Wiley Eastern, New Delhi

[17] Raihan F, Alam JB (2008) Assessment of groundwater quality inSunamganj Bangladesh. Iranian $\mathbf{J}$ Environ Health SciEng6(3):155-166

[18] Saha, Dipankar. Upadhyay, S.Dhar, Y.and Singh, R. (The Aquifer system and Evaluation of its Hydraullic parameters in parts of South Ganga plain), Bihar

[19] Shashank Shekhar1,Pandey.A.C2,Nathawat.M.S3 (Evaluation of fluoride contamination in groundwater sources in hard rock terrain in Garhwa district, Jharkhand, India)

[20] Todd, D.K. (2001) Groundwater Hydrology. John wiley \& sons, New York.

[21] WHO (1993) Guidelines for drinking-water quality, V.1. Recommendations Geneva: WHO.

[22] Wilcox LV (1955) Classification and use of irrigation water. US Department of Agriculture, Washington, DC 